\title{
A NEW PUBLIC NATURE: PARKS, PLANTS, AND PERIODICALS IN THE NINETEENTH CENTURY
}

\author{
by \\ Mark Sardella \\ B.A. Professional Writing, Institutional Communications \\ York University, Toronto, Ontario, 2016
}

\author{
A Major Research Paper \\ presented to Ryerson University \\ in partial fulfillment of the \\ requirements for the degree of \\ Master of Arts \\ in the English MA Program \\ in Literatures of Modernity
}

Toronto, Ontario, Canada, 2017

oMark Sardella 2017 


\section{AUTHOR'S DECLARATION FOR ELECTRONIC SUBMISSION OF A MAJOR RESEARCH PAPER}

I hereby declare that I am the sole author of this MRP. This is a true copy of the MRP, including any required final revisions.

I authorize Ryerson University to lend this MRP to other institutions or individuals for the purpose of scholarly research.

I further authorize Ryerson University to reproduce this MRP by photocopying or by other means, in total or in part, at the request of other institutions or individuals for the purpose of scholarly research.

I understand that my MRP may be made electronically available to the public. 
In 1798, William Curtis published the sixth and last volume of Flora Londinensis, a beautifully coloured catalogue of over 400 plants that grew in London and in its nearby fields. Less than 300 copies were sold, and while the book was considered scientifically important, it was a financial failure (Field 106). Firstly, Flora Londinensis was prohibitively expensive because of its coloured plates, and secondly, the many illustrations of wild grasses and common plants included in the book failed to interest an audience outside of a small group of medical doctors and aristocratic hobby-botanists. The project, however, was not a complete failure for Curtis. While publishing Flora Londinensis, Curtis launched a considerably more successful, similarly formatted periodical for a slightly broader audience called Botanical Magazine. Botanical Magazine featured coloured plates of newly discovered exotic plants that satisfied the tastes of the public. It was published in thin issues containing only three plates each, and at a price of one shilling per monthly issue, Botanical Magazine was affordable enough for more readers to justify paying for the magazine's exciting, colourfully illustrated content.

Botanical Magazine enjoyed considerable, but gradually waning, popularity until the mid-nineteenth century, when the magazine's mostly upper and upper-middle class subscribership dropped and the magazine nearly ceased publishing (Gardham, "Curtis's Botanical Magazine"). Illegal reproduction of images from Botanical Magazine, as well as competition from other similar magazines, was partly responsible for the magazine's struggles, but most importantly, by the 1850s Botanical Magazine failed to reflect the changing attitudes that Victorians had toward nature, botany, and science.

Mid-Victorian urbanites looked to local nature as a repose from urban sprawl and the overwhelming industrial expansion happening around them. Also, miasma theory suggested that taking trips to the newly opening public parks in English cities was a fun leisure activity and an 
important responsibility to maintain one's own health, as well as one's family's health (Repucci). Newly built suburbs featured green central squares, and neighbourhoods of villas were built to look like large parks, featuring rolling hills dotted with homes (Creese 50). As the urban landscape became greener, women authors popularized botany. They wrote about local nature in beautifully illustrated books, and they wrote textbooks for school children in narrative formats that were accessible and brought natural events to life that were previously thought of as mundane (Lightman 126). The books' new accessible narrative formats helped foster a strong fascination with the natural world, and the most dedicated nature lovers joined amateur field naturalist societies and clubs (English 96). Meanwhile, Botanical Magazine, with its focus on aristocratic-hobby botany, fell out of fashion. Fictional texts like Wilkie Collins' The Moonstone represented aristocratic botany as busywork that was pointlessly performed by the idle rich (146), while Elizabeth Gaskell's Mary Barton glorified the lives of working-class field naturalists and citizen scientists (55).

In 1865, Mordecai Cubitt Cooke, the head of a field naturalist club called The Society of Amateur Botanists that was similar to the fictional clubs portrayed in Mary Barton, published the first monthly issue of Science-Gossip, which aimed to mimic the amicable, inclusive tone of his field club's meetings (English 108). Science-Gossip cost four pence per monthly issue, and provided nature lovers of all classes with relevant, interesting, and up-to-date science news. It featured simple, linear diagrams that helped educate readers about nature and helped keep the magazine's price low. Science-Gossip's editors encouraged correspondence from non-expert readers who either had scientific questions or who had discovered new oddities in their backyards and neighbourhoods. Established, professional scientists published articles in the magazine as well. Science-Gossip's blend of high and low contributions makes it an important 
social and cultural artifact of the mid-nineteenth century, a time when citizen science enjoyed a golden age.

Looking closely at issues of Botanical Magazine from the early nineteenth century and issues of Science-Gossip from the 1860s, the magazines' differences highlight important changes in the representation of nature in the nineteenth century. Botanical Magazine's highly detailed, artistic representations of plants contrast with Science-Gossip's simple diagrams. The shift from ornamental copperplates to simple wood engravings complements botany's changing audience from wealthy aristocratic collectors to citizen scientists of all classes. Each magazine presents nature differently in its text as well. Botanical Magazine describes plants as part of owners' collections, and describes how plants were retrieved from foreign lands, while Science-Gossip describes plants as living beings that are publicly shared and should be appreciated in situ. Most importantly, each magazine as a whole reflects the different reasons readers valued nature during the periods that the magazines were the most influential and successful. In its early nineteenthcentury issues, Botanical Magazine reflects its readership's taste for plants that are rare, newly discovered, and beautiful. In its issues from the 1860s, Science-Gossip reflects its readership's taste for local plants that inspire amateur scientific investigations. As a result of the way each magazine represents a different way of understanding and valuing nature, Botanical Magazine and Science-Gossip, two drastically different periodicals, are surprisingly linked, and together they help narrate how the public's view of nature, public green spaces, and botany changed throughout the century.

\section{From Flora Londinensis to Botanical Magazine}

At first glance, William Curtis' Flora Londinensis and Botanical Magazine are visually quite 
similar. Both contain full-page copperplate engravings, which were hand-coloured using watercolour paints. Following each plate is a page or more of text, which includes the plant's name, its Latin name, and information about its family and genus. This is followed by detailed descriptions of the plant's roots, stalks, and leaves, and then paragraphs detailing where the plant grows and when the plant blooms. Comparing Flora Londinensis and Botanical Magazine's differences, however, gives insight into the tastes of late eighteenth-century botanists and gardeners.

Their differences emphasize both the type of plants readers were interested in, and why readers were interested in them. According to its full title, Flora Londinensis was meant to highlight the medical, agricultural, and other uses for plants. (The publication's full title is Flora Londinensis, or, Plates and Descriptions of Such Plants as Grow Wild in the Environs of London: With Their Places of Growth, and Times of Flowering, Their Several Names According to Linnoeus and Other Authors: With a Particular Description of Each Plant in Latin and English: To Which Are Added, Their Several Uses in Medicine, Agriculture, Rural Economy and Other Arts.) Most descriptions include a sentence about a plant's usefulness. For example, volume four features field scabious, a plant with small purple flowers. In the plant's description, it is stated that the plant is believed to help with symptoms of fevers and coughs when ingested and aids in the treatment of itches, scurvy, and scabies when applied topically (Curtis "Scabiosa Arvensis"). The publication, however, does not entirely live up to its title's claim. Curtis aimed to catalogue every plant, grass, and mushroom species within a ten-mile radius of London (Lazarus 16). As a result, many plants throughout the six volumes are described as having no known medical purpose or virtues. The inclusion of useless plants in Flora Londinensis must have frustrated the publication's subscribers, many of whom were medical doctors who might 
have subscribed specifically in hopes of learning more about the uses of easily available plants (“A List of the Subscribers to the Flora Londinensis"). If there were subscribers who were primarily interested in Flora Londinensis for its beautiful plates of local plants, there were not enough of them to keep the publication in print. Curtis never completed the full Flora Londinensis project, since it would have led to financial ruin (Field 106).

Botanical Magazine was founded precisely in an attempt to make up for the financial losses from publishing Flora Londinensis, so Botanical Magazine's content was specifically meant to please popular tastes and encourage as many subscriptions as possible. London's common grasses and mushrooms are not represented in Botanical Magazine. The usefulness of plants is rarely stated. Instead, the usefulness of the exotic flora featured, or the reason the flora was worth reading about, can be inferred. Owning or collecting exotic flora, grown in a greenhouse, was meant to be a pleasurable hobby, and reading the magazine was meant to be pleasurable on its own for its novel content. Botanical Magazine's full title, The Botanical Magazine; Or, Flower-garden Displayed: In Which the Most Ornamental Foreign Plants, Cultivated in the Open Ground, the Green-house, and the Stove, Are Accurately Represented in Their Natural Colours. To Which Are Added, Their Names, Class, Order, Generic and Specific Characters, According to the Celebrated Linnaeus; Their Places of Growth, and Times of Flowering: Together with the Most Approved Methods of Culture. A Work Intended for the Use of Such Ladies, Gentlemen, and Gardeners, as Wish to Become Scientifically Acquainted with the Plants They Cultivate, presents ornamental plants as having an almost pet-like status. The magazine's explicit purpose was for ladies, gentlemen, and gardeners to become more acquainted with the plants they cultivated. Using the flora in Botanical Magazine for practical purposes would be akin to using a lap dog to herd sheep. The uselessness or vulnerability of the 
flora featured in Botanical Magazine is important as well. Despite the title's suggestion that some ornamental plants featured could be cultivated in the open ground, many of the plants featured in Botanical Magazine could only survive in greenhouses (or stoves, which are greenhouses with additional heating components) making them all the more luxurious and exciting to read about. From the start, readers expressed their lack of interest in common plants. Curtis notes this in volume three:

It has been suggested by some of our readers, that too many common plants, like the present [see figure 1], are figured in this work. We wish it to be understood, that the professed design of the Botanical Magazine is to exhibit representations of such. We are desirous of putting it in the power of all who cultivate or amuse themselves with plants, to become scientifically acquainted with them, as far as our labours extend; and we deem it of mere consequence, that they should be able to ascertain such as are to be found in every garden, than such as they may never have an opportunity of seeing. On viewing the representations of objects of this sort, a desire of seeing the original is naturally excited, and the pleasure is greatly enhanced by having it in our power to possess it. But, while we are desirous of thus creating Botanists, we are no less anxious to gratify the wishes of those already such; and we believe, from a perusal of the Magazine, it will appear that one third of the plants figured, have some pretentions to novelty. (Curtis 77)

Curtis acknowledges the friction between his personal goals for the magazine and his readers' reasons for purchasing it. Since Curtis was an apothecary who was particularly interested in urban nature, Flora Londinensis must have complemented his interests more directly (BevanJones 25). While Curtis states his ideal intentions for the magazine - to create new botanists by encouraging an appreciation for both novel and common nature-Botanical Magazine was a 
commercial venture first and foremost. In fact, the success of the first issues helped fund the publishing of some of the last issues of Flora Londinensis (Field 106). So, in response to his subscribers' requests, Botanical Magazine published more exotic plants in subsequent volumes, which were almost exclusively limited to flora and fruit trees.

Acknowledging that he was publishing a magazine that aestheticized nature, Curtis anticipated that a portion of the magazine's readership would be interested in nature purely for its decorative purposes. In his description of a Christmas rose, he states: "As our Publication seems likely to fall into the hands of such as are totally unacquainted with Botany, or botanical writings, it must plead as an apology for our often explaining many circumstances relative to plants, which may be well known to adepts in the science" (Curtis 8). Here, Curtis is specifically referencing the redundancy of the magazine's entries, which describe the plant to the reader three times. First, the plant is depicted as an image, second, the plant is detailed in Latin in point form for trained botanists, and third, the plant is described at length in English for all audiences. As a result, the magazine's text starts to become noticeably obvious and repetitive, even for beginners. The descriptions are useful for identification though, since they help fill in information that the images cannot provide. Almost all of the images of plants in the magazine present them in full bloom, so the descriptions help make plants more identifiable at other stages. The detailed descriptions are also useful for another purpose: they serve the needs of decorators. The preface of volume 16 of Botanical Magazine, the first volume not published by Curtis, draws attention to its usefulness as a design reference:

The same Artists are employed in every department of the Work as in Mr. Curtis's time. This will, it is hoped, insure the same excellence of execution, which is such that the figures in the Botanical Magazine, for elegance as well as correctness, will in general 
suffer nothing by a comparison with the most expensive botanical works, a fact loudly attested by the circumstance that a large proportion of the ornaments of our most expensive porcelain and cabinet ware is copied from them. (Sims "Preface")

Written by Botanical Magazine's second editor John Sims in 1801, the passage shows the way nature was commodified at the end of the eighteenth century and the beginning of the nineteenth century. Nature, specifically exotic flora, was not only collected in physical form in the greenhouses and stoves of the gentry, but it was also used to enhance and beautify other possessions. Decorators beautified homes by designing fabrics, furniture, and porcelain that all featured representations of exotic flora copied from the magazine. Even the images in Botanical Magazine can be considered collectable art on their own. Every plate has a number, and the numbering continues across issues and volumes (up to 8873 in 1923), encouraging collection and consistent subscription. In the $1810 \mathrm{~s}$, the magazine introduced fold-out plates that begged to be repurposed. This is further illustrated by the number of reproduced images from the magazine that are still available today to buy as wall art, or the number of plates that have been carefully removed from some of the original surviving volumes of Botanical Magazine.

The magazine was also aspirational, since many early nineteenth century readers of Botanical Magazine would never see or own most of the plants featured in the magazine in real life. While readers might have had small conservatories or greenhouses, few would have owned large greenhouses or stoves like the ones that were regularly featured in Botanical Magazine. Large greenhouses were prohibitively expensive to build. Even subscribers who could afford the hefty price of three shillings per issue for the magazine by the 1830 s would not have been able to build a greenhouse. This was largely due to a glass tax, which limited the ownership of greenhouses to the ultra-wealthy until 1845 (Tait 247). As a result, the magazine would have 
been read by some subscribers the way contemporary readers might read about space exploration technology in Spaceport Magazine or happenings in the art world in Artforum. Like space exploration or art collecting, cultivating exotic plants was something that was interesting, glamourous, and continuously changing, making it enjoyable to read about even if one was not directly involved in the activities portrayed. Readers might have even hoped that someday in the future they would be able to own a small greenhouse, the same way readers of Spaceport Magazine might dream of space travel or how Artforum readers might dream of buying a work by their favourite artist.

\section{Botanical Magazine and British Imperialism}

The magazine was not strictly an aspirational collector's guide, however. It also recorded the progress of British imperialism by cataloguing new, exotic species that were brought to Britain from exotic locations, specifically to Kew Gardens. Under William Hooker's editorship, which spanned from 1827 to 1865, the magazine's connection with Kew Gardens intensified. Hooker dedicated the 1828 volume of Botanical Magazine to William Townsend Aiton, who was the director of Kew Gardens at the time, and in 1841, Hooker himself would become the director of Kew. He was both the director of Kew and the editor of Botanical Magazine until his death in 1865. In Nature's Government, Richard Drayton states that Kew was a "de facto national collection, to which seeds and bulbs were sent from every part of the world" (108). He also compares it to other royal gardens that were more for display than encouraging scientific progress, noting that Kew "was meant, like those at Schönbrunn or Malmaison, to add lustre to the court. The science of botany, itself, one may argue, found employment at Kew principally in an ornamental capacity: the display of knowledge was itself part of the spectacle" (129). As a 
result, contributions to Kew Gardens that were recorded in the magazine were described as important contributions to the nation. For example, "Mr. Bowie ... successfully explored the Botany of Southern Africa, and enriched the Royal Gardens at Kew with many of its choicest productions, in the summer of last year" (Hooker 2860). In this example, Bowie is successful in his exploration because he enriches the Royal Gardens. The purpose of his trip is explicitly to collect plants and improve Britain's collection. In another passage, Hooker describes Allan Cunningham's travels in colourful language, giving his travels an adventurous, heroic tone: “This interesting species of Grevillea was discovered by the King's collector, Mr. Allan Cunningham, on peaty bogs on the Blue Mountains, and banks of Cox's river, during Mr. Oxley's first expedition into the interior [of Australia] in 1817, and introduced to this country through the medium of the Royal Gardens at Kew." (Hooker 2807) As a medium for introducing plants to Britain, Kew was an important imperial institution. As a result, Cunningham's expedition is described similarly to Mr. Bowie's, and the trip's success was that it led to a contribution to Kew. Botanical Magazine articles always describe botanists' contributions to Kew in positive terms, but the magazine framed them as contributions to the wealth of the nation, not contributions to science per se.

Botanical Magazine's representation of newly discovered plants as decorative imperial trophies instead of objects of study had a negative effect on the public's perception of botany as a legitimate field of study in the first half of the nineteenth century. Events outside of the magazine damaged botany's reputation as a serious science as well. Leading botanists financially and socially relied on aristocratic gardeners to supplement their incomes and help advance their careers, which distracted from more important scientific work (Drayton 147). Drayton explains two of these relationships in detail when he describes how William Hooker and one of Botanical 
Magazine's illustrators, John Lindley, cultivated significant relationships with aristocratic growers of exotic flora:

Hooker established a connection with the Duke of Bedford, collector of orchids and pine trees, who arranged for him to be knighted on 20 April 1836 at His Majesty's levée. Lindley became the foremost British expert on orchids, and formed close ties with the Duke of Devonshire, naming a genus of plants after the man who feted him at Chatsworth. Both men spent a considerable part of their professional lives publishing botanical illustrations in small and costly engraved editions. (Drayton 147)

As Drayton shows, professional botanists, in effect, became collections assistants to aristocratic gardeners, and traces of the types of relationships Drayton describes can be found in Botanical Magazine as well. A description of a pitcher plant from volume 55 provides two examples. First, William Hooker presents Lindley as a liaison between another aristocratic gardener and the magazine: "Mr. Lindley has given me a specimen of our N. disillatoria, gathered at Macao, from J. Harrison, Esq." (Hooker 2798). Second, the reader is introduced to Mr. Cooper, a professional botanist, "who so ably conducts the gardens at Wentworth House" (Hooker 2798), which is a castle in Yorkshire that was owned by the Earls of Strafford (Charlesworth 626). In both passages, professional botanists work for aristocratic hobby-botanists, making their work seem more valuable for its contribution to the beauty of an estate than its contribution to the field of botany. This relationship also encouraged botanists to focus specifically on exotic plants instead of common plants, since aristocratic collectors were not interested in collecting common plants.

As Drayton notes in his passage, both botanists spent time publishing what he implies are inconsequential engraved editions for their patrons. The patrons, aristocratic gardeners, desired to have their collections permanently recorded in print. This is especially noticeable in issues of 
Botanical Magazine published in the 1820s and 1830s. In these issues, the plant's descriptions often contain information about the collectors themselves, who are praised for their carefully curated collections. Collections are often valued for their beauty and rarity. For example, Hooker draws attention to the social status of a plant's owner when he describes the provenance of a black-flowered gonolobus, which was "raised from seeds sent from Mexico to the Rev. J. T. Huntley of Kimbolton, a gentleman, whose collections of living plants promises to rank among the most valuable in the kingdom for rare and beautiful individuals" (Hooker 2799). As a result of the continuous reference to earls, dukes, castles and estates, Botanical Magazine had the tone of a private club in the 1820s and 1830s.

The magazine's intensifying connection with Kew under Hooker's editorship also contributed to the magazine's clubby tone during the 1820 s and 1830s. At the time, Kew was still a private royal garden. Drayton explains why, under the directorship of William Townsend Aiton, gardeners, nurserymen, and other members of the scientific community were upset by Kew's exclusivity:

Aiton had jealously kept from the English public both many Cape, Australian, and Indian plants collected in the era of Banks, and other new acquisitions, such as the orchids which Aldridge returned from Trinidad and the Orinoco delta in 1833. In the late 1830s, the gardeners thunderingly demanded access to Kew, in the name of public interest. (153) The gardeners Drayton refers to were members of the Royal Gardens Committee, which was a society for professional botanists. As one can imagine, Botanical Magazine's increasing coverage of the species at Kew Gardens must have angered some readers, since Kew received many interesting species that were essentially locked in a royal vault. While the magazine did increase the visibility of Kew's plants by publishing articles and pictures of them in print, the 
publication must have also acted as a reminder of what was inaccessible to readers who did not have the type of advantageous connections that would give them access to the species at Kew. This must have been especially upsetting to those who would have benefitted from studying the plants in person.

Eventually, the Royal Gardens Committee's demand to make Kew publicly accessible was a success. Kew Gardens was transferred from the Crown to the British government in 1841 (Drayton 153). The same year, William Hooker became the director of Kew and opened the gardens to the public on weekday evenings and Sundays (Willes 214). Despite the magazine's close connection with Kew, which was now publicly accessible and should have increased interest in the magazine and its featured flora, the magazine struggled.

In the 1840 s the magazine appears to have been facing an identity crisis. While the descriptions of plants continued to present botany in a clubby tone, the images in the magazine were becoming more scientific looking and less decorative. A good example of this is the illustration of a tufted-flowered horkelia in volume 56 (see figure 2). Included on the page is an image of a single flower (1), a dissected section of flower that shows the stamens (2), the flower's pistils (3), the receptacle (4), and a single magnified pistil (5). Behind the flower is a picture of its root leaf that is not coloured in to show the viewer the leaf's hairy texture more clearly and to place it in the background. While these images were certainly more helpful for botanists, other publishers were publishing more decorative prints of flora at the same time, which the public preferred (Gardham, "Curtis's Botanical Magazine"). On top of this, the images in Botanical Magazine varied in quality because low-wage workers painted the copperplates by hand. Hooker switched from copperplates to lithographs in 1845, but the new lithograph images were also poorly coloured. The image of a shining-leaved brunfelsia in volume 73 is a good 
example (see figure 3). Compared to earlier prints, there are fewer hue gradients. Instead, dimension was mainly achieved with the image's black and white shading. As a result, the images look flat and cheaply produced. By 1848 , the magazine sold only 300 copies an issue (Gardham “Curtis’s Botanical Magazine”).

\section{Popularizing Nature}

Quality issues and changes in visual style were not the only reasons for Botanical Magazine's mid-century struggles. By the 1840s, the public's experience and understanding of nature had changed considerably thanks to the opening of the Derby Arboretum. The Derby Arboretum "was the first specifically designed, municipally owned, public park in Britain" (Elliot 144). The park had hundreds of labeled shrubs and trees, which were grouped by type and were sometimes exotic (Butterton 62). In some ways, the Derby Arboretum was like a three-dimensional version of Botanical Magazine, where one could see new species and learn about them at once. Unsurprisingly, the opening of the Derby Arboretum was an enormous success, attracting thousands of visitors (Butterton 62). In his history of the Derby Arboretum, Paul A. Elliot explains the arboretum's importance and influence on urban planning as "an example of how local initiatives in provincial towns drove the Victorian municipal revolution, rather than central government legislation" (144). Elliot also notes that one of the arboretum's unique characteristics was that it was designed for "public edification" (144). This characteristic is important, since common lands and royal parks existed for centuries before the opening of the Derby Arboretum. Unlike the Derby Arboretum, however, the botanical landscape of common lands would have been difficult for visitors to navigate or appreciate without an expensive field guide like Flora Londinensis. Also, royal parks were never specifically designed for public 
edification before 1840, and were instead were used strictly for recreation. Hyde Park for example, was used in previous centuries as a celebratory space, as a safe haven from the plague, or as a hunting ground depending on the century (Walford 383). Following the success of the Derby Arboretum, Crown lands and royal parks were repurposed for public use. Victoria Park in East London is a particularly good example of this phenomenon. Victoria Park was built in 1845 on Crown-owned land that was previously used as a clay quarry (Willes 214). As Margaret Willes notes in her book The Gardens of the Working Class, East Londoners likely had little interest in the contents of Kew or other botanical gardens because they were irrelevant to their daily lives (214). Working-class East Londoners could not afford periodicals like Botanical Magazine that brought the contents of Kew to life. Also, all of the existing royal parks in London were exclusively located in the West End, so the opening of Victoria Park in East London was a particularly important step toward giving the working class access to green space, which offered them a refuge from their crowded living spaces (Willes 214).

To Victorians, parks offered even more than just a space for relaxation. Public parks were understood to be important for public health, too. Before the opening of Victoria Park, William Farr, a respected sanitary reformer, stated "a park in the East End of London would probably diminish the annual deaths by several thousands ... and add several years to the lives of the entire population" (Willes 215). Farr, as well as other sanitary reformers, believed that parks could be carefully landscaped with soft hills and valleys to provide visitors with continuously circulating fresh air, which would improve people's health (Repucci). This view was supported by the now defunct miasma theory, which was the belief that diseases like cholera spread through the inhalation of contaminated, or foul-smelling air (Repucci). For urbanites, who were accosted with the smell of rotting garbage, smoke from coal fires, and horse droppings all day, parks were 
a sanctuary from the dangers of city air.

While parks were being built in cities, park-like neighbourhoods, or suburbs, were being built around them. The Victorians' passion for green space, and the belief in its positive health effects, inspired a frenzied building of suburban villas with grassy lawns. Walter Creese explains the essential format of a nineteenth-century suburban villa in his chapter "Imagination in the Suburb." Importantly, Creese quotes Loudon, a pioneer of suburb design and Derby Arboretum's architect, who states his beliefs about the importance of nature:

J. C. Loudon announced his intention to prove 'that a suburban residence, with a very small portion of the land attached, will contain all that is essential to happiness, in the garden, park, and demesne of the most extensive country residence.' Thus, the quiet contemplation of ever-more-distant views, great sweeps of lawn, and a nearby private wood [of a country estate] was replaced by a far more packed and animated scene-a close-cut lawn, graveled paths trimmed with bright flowers, floral beddings in variegated patterns, ornamental ponds, statuary, tents, an iron fountain, and often, right up against the house, the glass bubble of a conservatory. (50)

Creese describes the suburb as an over-landscaped, kitschy natural wonderland with its mix of textures and ornaments. The suburb's artificial landscapes took a dizzying amount of maintenance, as Creese suggests with his list of the different components of the suburban villa's outdoor scene. Unlike a country estate or a castle, in a suburban villa the act of keeping plants alive and keeping grass cropped was not outsourced to greenhouse managers or groundskeepers. Instead, the middle class gardened. Magazines like The Gardeners' Chronicle (1841 to present) and books such as The Ladies' Companion to the Flower Garden (1851) taught the middle class how to garden. While these publications dealt with topics like landscape design and the beauty of 
flowers, they also taught practical lessons in botany and biology to their readers. As a result, by the 1850s, the Victorians had developed a keen interest in the science of the world around them. In Victorian Popularizers of Science, Bernard Lightman notes that the Great Exhibition, held in 1851, further encouraged the public's interest in the sciences, and even brought nature indoors. Lightman explains that during the 1850 s, "the aquarium became a national craze, and members of the British middle class traveled to the coast to comb the beaches for specimens. At the same time, fern collecting became a widespread fad" (1). Like the aristocrats featured in Botanical Magazine, the middle class enjoyed collecting natural specimens and learning about nature. However, unlike aristocratic collectors who collected exotic plants retrieved from far off lands, the middle class collected plants and specimens from nearby fields, woods, and seashores. Importantly, middle-class Victorians' fern collections were not necessarily valued for their rarity. Instead, the collections represented their owners' scientific interest in the natural world. In response to, and perhaps contributing to, the interest in ferns, several books dedicated to ferns were published in the 1850s for middle-class audiences, including A Plain and Easy Account of British Ferns by Phebe Lankester and The Ferns of Great Britain by Anne Pratt.

Authors like Lankester and Pratt were particularly important in popularizing botany and fostering the public's scientific interest in nature. Lightman notes that female authors specifically wrote for an audience that had not previously studied botany (126). Some of the newly published botanical books included aestheticized illustrations of nature. Similar to early issues of Botanical Magazine, the aestheticized images helped attract new audiences who had previously not been interested in botany. Anne Pratt's books, for example, were beautifully illustrated (see figure 4). Instead of restricting herself to exotic flora, however, Pratt wrote about plants that could be discovered domestically, making her work even more accessible to beginners. Her books 
encouraged readers to explore the local natural landscape, especially two of her titles: The Field, The Garden, and The Woodland, which was published in 1838, and The Flowering Plants, Grasses, Sedges, and Ferns of Great Britain and Their Allies the Club Mosses, Pepperworts, and Horsetails, which was published in six volumes between 1855 and 1873.

Alongside books about ferns and woodland plants, female popularizers of science wrote books for children that used simple language and new narrative formats (Lightman 128). Pratt, Lankester, and others moved away from the type of expository prose and tales of exploration and discovery that were characteristic of Botanical Magazine and other male botanists' publications. Instead, they introduced narrative formats that focused on the life cycles of plants and their seasonal changes (Lightman 130). This was especially important in books that did not have illustrations in them, such as Lankester's Wild Flowers Worth Notice. Her accessible, friendly tone is noticeable in her description of the globeflower:

In Scotland it is called Lucken Gowan, or Cabbage Daisy. In some parts of England, as well as on the continent of Europe, they are gathered on festive occasions for making garlands and decorating the cottages of the peasantry. In common with its natural order, this plant is slightly acrid. It likes a rich, moist soil, but loves a good strong light to flourish under; deriving vigour and colour as the moon derives her light. (6) Lankester details the flower's social relevance, that it is used for festive occasions, in a way that makes the flower memorable. Then, she personifies it in the passage. The globeflower likes rich soil, loves strong light, and derives vigour like the moon. Unlike the descriptions in Botanical Magazine, which describe plants as if they were subjects of a still life painting, Lankester's work anthropomorphizes nature in a way that reminds the reader that plants are living things. As anthropomorphized nature, plants could be reworked into narratives about families, social 
hierarchy, and morals. Using nature as a tool for teaching important social lessons helped soothe the nerves of Victorians who were worried that an increased interest in science might work against religious teachings (Lightman 147).

Lankester's work, however, consistently presents the beauties of nature as one of God's gifts. Wild Flowers Worth Notice's preface includes the details of a conversation Lankester had with a preacher that partly inspired her book. Lankester concludes the preface with this passage from Wordsworth, which helps demonstrate her intentions for the book:

God made the flowers to beautify

The earth, and cheer man's careful mood;

And he is happiest who has power

To gather wisdom from a flower,

And wake his heart in every hour

To pleasant gratitude. (xii)

By quoting Wordsworth, Lankester also makes it clear that she aims to use botany as a tool for further appreciating, not scientifically deconstructing, the natural world. She states her general mission is to encourage an appreciation for God's nature in her preface, and she also incorporates religion into her plant descriptions. For example, she weaves together botanical teachings and social narratives when writing about mistletoe. She introduces it by highlighting its social relevance, rhetorically emphasizing that it is worth studying, and she presents mistletoe as an important reminder to appreciate God's gifts at Christmas time:

Our next plant is associated with thoughts of pleasant meetings and festive boards, and happy are those whose homes are filled at Christmas time with the cheerful companions of summer rambles, having health and spirits to enjoy the good gifts of God in any form. 
The Misletoe [sic], or Viscum album, is one of a genus of parasitical plants belonging to the family Loranthaceae, and is the only British representative of the family. (Lankester 65)

In the last sentence of her passage, she abruptly moves into more scientific information about mistletoe. In the paragraphs that follow, she continues to shift from social history to botanical information. She explains how mistletoe was once believed to be sacred and how it became associated with Christmas, and she concludes her entry with a transcription of a poem that features mistletoe (66). She also provides information about mistletoe's germination, details about its unusual inability to absorb fluids, and where and when it usually grows (66-67). Her entry, and her book as a whole, uses accessible historical information and hypothetical stories about everyday life to introduce headier scientific information. This made botany digestible, and it made botany seem culturally relevant.

As a result of the success of female authors like Lankester and Pratt, by the 1860s botany was a people's science. In contrast, aristocratic hobby-botany was presented in some popular media as ridiculous busy work that was out-of-touch with the broader scientific landscape. As Drayton states in regard to William Hooker, "The cruel consequence of gentlemanly science was that the lustre of an individual's talents was difficult to distinguish from the brilliance of his connections" (146). However, the most biting criticisms of aristocratic hobby-botany appear in fiction. In Wilkie Collins' The Moonstone, Gabriel Betteredge, a house steward, suggests to readers that his employers' botanical hobbies are nothing more than cures for idleness:

Gentlefolks in general have a very awkward rock ahead in life — the rock ahead of their own idleness. Their lives being, for the most part, passed in looking about them for something to do, it is curious to see- especially when their tastes are of what is called the 
intellectual sort-how often they drift blindfold into some nasty pursuit. Nine times out of ten they take to torturing something, or to spoiling something — and they firmly believe they are improving their minds, when the plain truth is, they are only making a mess in the house ... you see them occupied for hours together in spoiling a pretty flower with pointed instruments, out of a stupid curiosity to know what the flower is made of. Is its colour any prettier, or its scent any sweeter, when you DO know? But there! The poor souls must get through the time, you see —-they must get through the time. You dabbled in nasty mud, and made pies, when you were a child; and you dabble in nasty science, and dissect spiders, and spoil flowers, when you grow up. (Collins 32-33)

Luckily for Betteredge, the novel's protagonists choose to paint a mural on a door to cure their idleness instead of spoiling flowers and making a mess, but Betteredge's opinion that the dissection and study of plants is futile reflects a shift in the way that botany was being studied in the middle of the century. The public was more interested in appreciating nature as it grew in their gardens, or in the fields by their homes. In The Moonstone, this preferred method of nature appreciation is represented by Sergeant Cuff, who has a passion for roses and eventually retires to the suburbs to pursue rose cultivation whole-heartedly. His aesthetic appreciation for roses, as well as his expert knowledge about their cultivation, marks a nice midway point between Botanical Magazine and Science-Gossip. Cuff's interest in British roses pushes him away from the exotic-craving Botanical Magazine set, and his appreciation of the garden-grown rose for its aesthetic qualities in particular pushes him away from the Science-Gossip set, who were more scientifically purist in their pursuits of appreciating and studying the natural world.

A good fictional example of the scientifically purist pursuits of citizen scientists and field naturalist that best represent the ideals of the Science-Gossip set can be found in Elizabeth 
Gaskell's Mary Barton. The narrator presents citizen scientists and field naturalists as important cogs in the wheels of professional science. Since the novel takes place in Manchester, they are introduced as a group of unnamed, unrecognized inhabitants of Manchester: "There is a class of men in Manchester, unknown even to many of the inhabitants, and whose existence will probably be doubted by many, who yet may claim kindred with all the noble names that science recognises" (Gaskell 55). The group the narrator describes includes mathematicians, entomologists, physicists and other geniuses that work as hand weavers and labourers by day, but in their free time pursue science. The narrator describes field naturalists as scientifically knowledgeable despite their simple lifestyles:

Equally familiar with either the Linnæan or the Natural system, who know the name and habitat of every plant within a day's walk from their dwellings; who steal the holiday of a day or two when any particular plant should be in flower, and tying up their simple food in their pocket-handkerchiefs, set off with single purpose to fetch home the humblelooking weed. (Gaskell 56)

In a short fictional anecdote that proves the expertise of these local geniuses, Sir James Edward Smith (who was a real life botanist) looks for information about a specific plant from Roscoe of Liverpool (presumably meant to represent William Roscoe). When Roscoe does not know the answer to Smith's question, he refers him to a handloom weaver in Manchester. To Smith's surprise, the handloom weaver in Manchester and a porter are both expert botanists, and they provide him with the information he needs (Gaskell 56-57). While the anecdote is fictional, it might have been inspired by the pub-based botanical clubs that were beginning to form in the middle of the century throughout the England. The clubs usually met on Sundays, the only day off for the working classes, and because the groups met in pubs, they did not require membership 
fees, which prevented the working class from joining more legitimate natural history societies (English 96). By the 1860s, field clubs, which were a blend between pub-based clubs and more legitimate natural history societies, began to flourish (English 96).

\section{A New Publication for Lovers of Nature}

A particularly important field club was the Society of Amateur Botanists, led by Mordecai Cubitt Cooke, who would eventually become the editor of Science-Gossip. The Society of Amateur Botanists welcomed both established botanists and working-class field naturalists. Its low-priced subscription, which allowed working-class members to maintain their memberships, was thanks to the patronage of Robert Hardwicke. Hardwicke, who had previously published many popular science books, including Lankester's Wildflowers Worth Notice, partnered with Cooke, who wanted to publish a magazine specifically dedicated to popular science. In 1865 the first issue of Science-Gossip was published. Its full title was Hardwicke's Science-Gossip: An Illustrated Medium of Interchange and Gossip for the Students and Lovers of Nature. Cooke's intention to publish the magazine as an extension of The Society of Amateur Botanists set it apart from other popular science books and botanical magazines. Cubitt aimed to replicate the conversational and amicable tone of the society's meetings, and most importantly he encouraged participation from readers. In the opening essay of the first issue of Science-Gossip called "What's Your Hobby?" Cooke encourages readers to take to the fields:

"What is your hobby?

Should you have a friend addicted to the habit of bringing home bits of wild flowers in his hat, mosses in his pocket, or occasionally be caught with a flat, brown, japanned sandwich box, when you know that he never carries sandwiches out in it, but will be seen 
to bring home many strange things in it ... ask of him whether the pursuit, of his study of plant-life, of wild flowers, of mosses, does not give an interest to every half-hour's stroll along a hedgerow or into a wood, which it would not otherwise possess; whether it has not given to him a new sense; whether it has not unfolded to him a new world; whether, in fact, he is disposed to relapse again into inanition; and the chances are that he will ask you, good-humouredly enough, in return, "What is your hobby?" (2).

Cooke presents an interest in science and botany as personally enriching. The reader's friend, who enviously has a hobby, is presented as a busy eccentric, carrying strange things in his sandwich box. He is also a man of the mind, whose passion for his hobby regularly leads to inanition. Importantly though, his resourceful use of a japanned sandwich box to collect his strange things suggests that, even with makeshift tools, anyone can enjoy being a field naturalist. In another article called "Common Things," Cooke even shows a preference for workingclass field naturalists, and he echoes some of Gabriel Betteredge's sentiments from The Moonstone. Cooke explicitly criticises the collection and consequent extermination of rare plants. Like Betteredge, he notes the pointlessness of destroying the plants, but Cooke goes further, stating that the restlessness of rare species collectors is ridiculous and pointless. $\mathrm{He}$ suggests that cultivating a closer acquaintance with common plants, not amassing a vast collection of rare plants, is the best way to appreciate nature:

The fancy for collecting rare plants, or rare insects, is with some enthusiasts such an infatuation that they will undergo on its behalf all kinds of privation and toil, now rushing in one direction, and now in another, as if they thought that their credit here, and their salvation hereafter, depended upon the number of rare plants or animals they had aided in exterminating. It is not the rare but the common species which give character to a flora or 
fauna, and the time spent in hunting after, or travelling for miles in pursuit of some rarity, would be better employed in cultivating a closer acquaintance with such 'common things' as 'buttercups and daisies.' (Cooke 218)

Cultivating a closer relationship with nature was an important goal for field naturalists like Cooke, who were both interested in studying nature, and preserving it. Field naturalists, as opposed to botanists, were not necessarily professional scientists. Instead, like citizen scientists, many field naturalists were interested in science as a hobby. Thus, Cooke's statement, which privileges the appreciation of common species over the collection of rare species, implies that the work of field naturalists was more valid than the work done by aristocratic collectors.

In fact, the magazine promotes an approach to citizen science and naturalism where, ideally, the stresses of bourgeois and aristocratic society are left behind, and untouched nature can be appreciated in its full beauty. In Cooke's preface to the third issue of the magazine, titled "Short Commons," he expresses his disappointment regarding the construction of parks and suburbs on what were previously common lands. Cooke unhappily notes that Hampstead Heath had been recently "laid out into squares" (49). He also states that he fears that Wimbledon would be "laid out in tiny parallelograms of level grass, intersected by the cleanest gravel walks" as well (49). In the article, Cooke shows a preference for untouched nature, and a distaste for trendy suburban plants like chrysanthemums, when he describes the future sterilization of London's last untouched landscapes:

Let our friend the mechanic, who has for five days and a half laboured in hope that during the latter half of the sixth day he shall run down to Wimbledon to collect a few plants or insects, hear the birds sing, scramble amongst the furze, and feel the cool fresh breeze blowing the smoke out of his hair, pause a while, and picture to himself a future. In that 
day there shall be no more furze, or heather, or buttercups and daisies; the bluebell and the fern must give place to asters and chrysanthemums, and the furze be uprooted that the laurel and Aucuba [spotted laurel] may stand in its place. No daisy must dare to bloom in the shorn grass under peril of decapitation ... In that day the gravel walks will be trim and neat, now straight as an arrow, now winding in graceful curves, through lawns, and groves, and dells, adorned by shrubs, and trees, and flowers, too well trained to grow crooked, or stunted, or with undue luxuriance. (49-50)

Cooke's description of over-landscaped nature is similar to Creese's description of midnineteenth century suburbs, with their heavily groomed, geometric flowerbeds and walkways. Also, Cooke's fear - that the shrubs, trees, and flowers planted in these perfectly landscaped parks would be so well-trained that they would all grow identically—connects the building of parks and suburbs with what must have been his distaste for mass production and mass consumption. Cooke's statements might have complemented his readers' points of view, but his call for the preservation of the natural landscapes and his fear that London would become a boring, geometric, and over-landscaped space goes slightly beyond what the rest of his magazine promotes. In reality, many of the magazine's correspondents wrote to the magazine asking about the plants, birds, and bugs that they saw in local parks, or in their own backyards. Part of Science-Gossip's success was its focus on mundane nature, or at least, what could be considered mundane nature in comparison to the never-to-be-seen-in-person exotic plants published in Botanical Magazine. Unlike Flora Londinensis even, Science-Gossip focused strictly on the most common plants, not every single type of plant that could be found.

An article in the May 1865 issue of Science-Gossip called "On Some Imperfectly Developed Flowers" is a good example of how the magazine presented common plants to readers 
in a way that made them interesting to read about. The article features clovers, pears, primroses and grasses that grew in unexpected ways. None of the plants are particularly obscure. For example, Robert Holland, the article's author and a regular contributor, describes his own experience, stating "a cucumber grew a few years ago in my own garden, where one of the short prickles upon the fruit had grown out into a long curled tendril"' (105). Holland explains that he would like to write a more formal essay on the interesting branch of imperfect specimens, hoping that for beginners, his observations could not "fail to be of some use in the cause of botanical science" (105). Holland's half-belief in his observation's usefulness, highlighted by his italicized "some," captures the open-mindedness of the citizen science community in the 1860 s, and even the scientific community as a whole as it became increasingly accessible to the public.

Science-Gossip not only celebrated simple science, it encouraged simple language as well. The magazine published "A Hint for Contributors," which asked all contributors to use common plant names in their descriptions instead of scientific names, so that all readers could more easily understand their contributions. It states, "as we do not pretend to address scientific readers alone, vernacular names are indispensible" ("A Hint for Contributors" 120). ScienceGossip published articles celebrating regionally specific vernacular names, a move that worked directly against former publications like Botanical Magazine, and even some early popular science books whose authors still included plants' official Latin names and organized their content using the Linnaean system. Holland's article "Notes on Local Names" makes a strong case for vernacular names in the February 1865 issue:

I have often thought, that a complete collection of the names by which our British plants and animals are known in country places would be interesting, and would be, besides, not without its utility. Many of these names are exceedingly pretty, far prettier than those by 
which they are generally known, —at any rate in works on Natural History. Some conjure up poetical associations, or remind us of traditions or stories connected with the plants themselves, or point out uses which have, perhaps, now become obsolete. Many local names, too, are no doubt very ancient; some being of Saxon, some of Norse, and others of Celtic origin; and these ancient names would be a very sure means of determining whether the plants which bear them were true natives, or were introduced amongst us, and by whom, in later times. (35)

Holland's article, like many of his articles published in Science-Gossip, is experimental and entertaining. He blurs the boundaries between what is traditionally considered useful or useless when studying botany. He argues that some names are worth remembering for their poetic value alone, and that some may reveal the origins of plants. Importantly, "Notes on Local Names" captures the spirit of Science-Gossip, which was as much about getting entertainment from science through open-mindedness and inquisitiveness as it was about becoming more knowledgeable.

Science-Gossip's entertaining and friendly prose, written by writers like Holland, helped foster a lively correspondence section. Correspondents often wrote in with valuable information that contributed to the magazine's articles, and sometimes conversations started between correspondents themselves. For example, a correspondence by B titled "Jerusalem Artichoke" responds to a question asked by J.G. in the previous month's "Notes and Queries" section, which asks whether the Jerusalem artichoke ever blooms in England. B responds: "On page 118 I observe a query: 'Does this plant ever flower in England?' In 1861 I saw several specimens blossom in a kitchen-garden in Brompton, Middlesex ... They much resemble those of the common sunflower, a member of the same genus, but are smaller in size" (143). Conversations 
between readers held in the correspondence section mimicked the type of conversations that might happen at field club meetings. Science-Gossip, as an extended, paper-based version of a field club, was a success.

To enable collaboration and correspondence from readers, Science-Gossip had to be both a forum and a learning tool. Images were crucial to the magazine's educational efforts. Unlike Botanical Magazine's expensively produced artistic images, Science-Gossip had inexpensive, black-ink wood engravings on its pages, specifically when images were meant to be used for reference. Also unlike Botanical Magazine, many of Science-Gossip's images were instructional and informative, and were meant to complement the magazine's text instead of vice versa (see figure 5). Instead of full-page plates, images were set into the text. Each image's minimal detail made it useful, but certainly not a collectable like the detailed, pullout images found in Botanical Magazine were. The article "Leaf Teachings" by Wallace Fyfe is illustrated with line engravings of Beech, Cherry, Lime, and Poplar leaves that function as diagrams (see figure 5). The diagrams give just enough detail to help readers identify each leaf. Rhetorically, the exaggeratedly simple, technical style of the instructional images seems to contrast the elaborately illustrated and coloured images that were found in earlier scientific publications. Keeping Cooke's dislike for aristocratic botany in mind, the images seem to intentionally challenge the existing, more elaborate popular styles of botanical drawing, which aimed to feature every detail of plant, whether it was relevant to its identification or not. In contrast, Science-Gossip images were meant to complement the text, but also be secondary to nature. Botanical Magazine, which featured illustrations that were always in full bloom and bursting with colour (see figure 6), exaggerated the beauty of nature and seemed to try to better it on the page. Science-Gossip, on the other hand, presented a skeleton of nature that encouraged readers to seek out the real thing. 
Even issues of Science-Gossip published toward the end of the century continued to contain simple, albeit neater, scientific images (see figure 7). Whether intentionally or not, the magazine must have partly influenced the undecorated, minimalist style that scientific drawings, technical drawings, and diagrams still have today.

Science-Gossip's many simple, linear images helped keep subscription prices low, but the magazine did occasionally have more detailed and decorative images in it as well. For example, Cooke's editorial article "Toadstools" encourages readers to appreciate fungi, and it is accompanied by a vignette with two anthropomorphized toads and a dragonfly flying in the background (see figure 8). Since the article is meant to encourage an appreciation of nature, not necessarily be a lesson on toadstools, the image is appropriately more whimsical. The magazine appears to split artistic and instructional images stylistically: art images could contain superfluous detail and have narratives within themselves, while non-art images were noticeably spartan by comparison, delivering readers with just the crucial information needed to complement the text's message.

Visually, Science-Gossip's blend of both scientific and artistic images hints at its uniqueness as a magazine. Unlike magazines and science books before it, which were geared directly to an exclusively professional or an exclusively nonprofessional audience, ScienceGossip attracted both professional readers and hobbyists. This is best exemplified by Charles Darwin's contribution to the magazine in 1867 (280). His contribution was not as an author, but as a correspondent in the "Notes and Queries" section of the magazine, showing that he, too, read Science-Gossip. Slightly outside the realm of botany, he responds to an article that was published in an earlier issue about hedgehogs. In the article, an author states that he was shocked to see a hedgehog transporting a pear on its back (B. L. 185). Darwin writes in response, stating 
that he has heard of hedgehogs doing the same with strawberries in Spain (280). When he wrote in to the magazine in 1867, Darwin had already published On the Origin of Species, so his contribution to Science-Gossip shows just how blended the periodical was in terms of readership. Later in the century, and into the twentieth century, the institutionalization of science would split publications into two groups: popular science magazines and academic science journals. Citizen science would eventually lose its legitimacy in the process. Science-Gossip continued to be directed toward a mixed popular and professional audience throughout its run. It remained successful until the 1890s, but eventually ceased publication in 1902.

As science became increasingly institutionalized, some popular magazines that were similar to Science-Gossip would develop into respected science journals for professionals. Nature (1869-present), for example, would begin to transform from a conversational, casual science magazine like Science-Gossip to the highly cited science journal it is today toward the end of the century (Browne 248). National Geographic (1888-present) would move in the opposite direction, shifting from being a professional science journal to a popular magazine in the twentieth century, particularly as it incorporated more images onto its pages (Hawkins 51). Importantly, these two surviving magazines show how publications became more strictly delineated as professional or nonprofessional, making Science-Gossip a unique cultural artefact of the citizen science age. The blended contributions by both professionals and amateurs, as well as the magazine's mixed readership, make it comparable to today's open-source software building environment. The contributions of both experts and novices are valued, and necessary, to make progress.

\section{Conclusion}


Moving from Flora Londinensis, to Botanical Magazine, to popular botanical books, to ScienceGossip shows how publications about nature changed drastically in the nineteenth century. Flora Londinensis' failure helps explain Botanical Magazine's success, since their similar format, but varying content, highlights the public's taste for exotics over common plants during the first half of the century. The popularity of amateur science books featuring local nature in $1850 \mathrm{~s}$, on the other hand, can only be explained by the cultural shifts happening off the page, such as the construction of the first public parks and the building of suburbs around metropolises like London. While Botanical Magazine survived during the mid-century boom of appreciation for common plants, its near failure shows how shifts in the public's tastes for certain types of nature can be compared to a pendulum swinging. Instead of an increased access to local nature inspiring an interest in all types of nature, it seems the taste for exotics waned. Or, at the very least, the popularity of publications about common nature outshone the interest in exotics. Seventy years earlier, readers of Botanical Magazine had complained that there were too many common plants being published in Curtis's magazine. By the 1860s whole books and magazines were dedicated to common plants exclusively.

Both Botanical Magazine and Science-Gossip leave their legacy today, and an appreciation of local nature and exotic nature thrive simultaneously in seemingly equal measure. Television programs like Planet Earth present viewers with untouched, exotic nature in beautifully filmed documentaries that sensationalize nature in a similar way to Botanical Magazine. Homes, offices, and computer desktop backgrounds are beautified with images of exotic flora. In some spaces, elegant botanical illustrations, and their reproductions, are used as wall art. We continue to grow exotic decorative plants in our homes or in our gardens if the local climate permits it, and of course, our taste for colourful and dramatic flora is healthy. Kew 
Gardens is a popular tourist attraction, and nature lovers travel across the globe to visit rainforests and exotic plants as ecotourists. Science-Gossip and other accessible science and botany publications helped maintain the broader public's interest in local nature that started in the middle of the nineteenth century. Hundreds of field naturalist clubs still exist all over the world that aim to appreciate, protect, and preserve the native plants in their own communities. Public television channels broadcast accessible and interesting science programs that feature experts in their field, and magazines like Popular Science do the same. Most importantly, perhaps, Science-Gossip and Botanical Magazine helped make nature worth noticing. The influence of both magazines is truly still present, whether we visit a grand botanical garden and ogle at gigantic tropical leaves, or simply enjoy the pleasant sight of a local wildflower growing in an unexpected spot. 
Figures

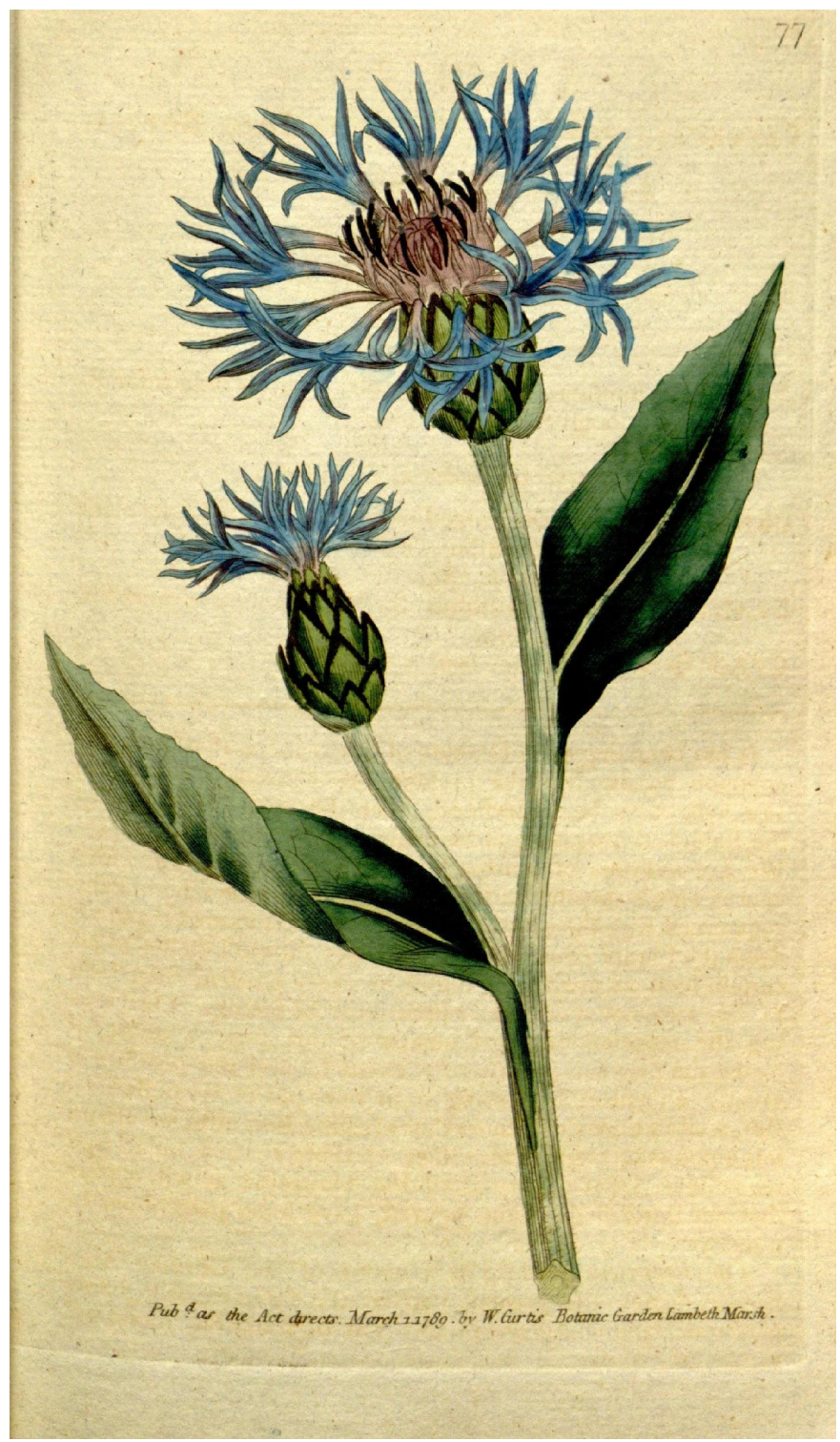

Figure 1 James Sowerby. “Centaurea Montana.” Botanical Magazine, vol. 3, 1790.

Biodiversity Heritage Library, 2006, biodiversitylibrary.org/page/469099. Accessed 26 May 2017. 


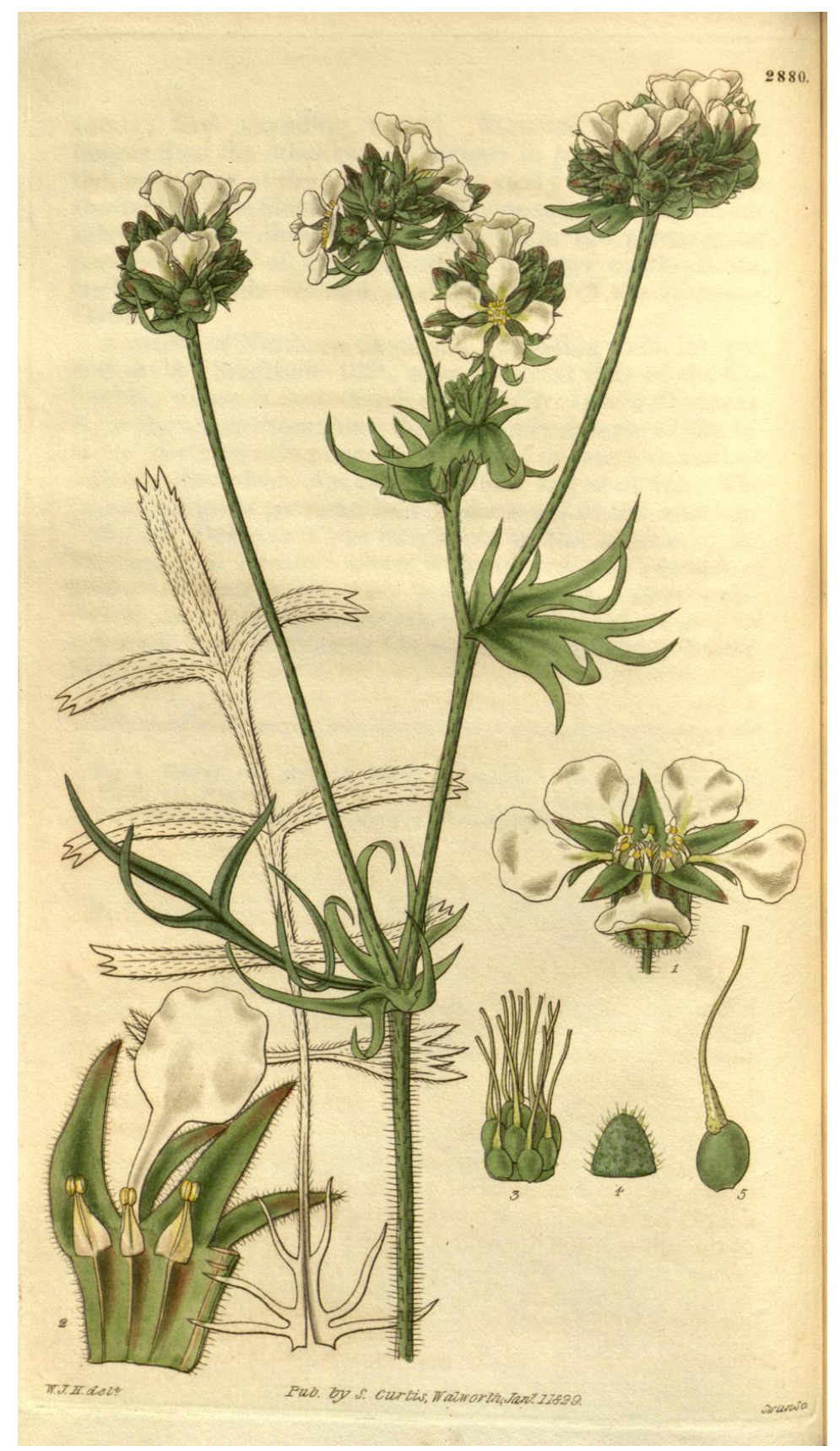

Figure 2: William J. Hooker. "Horkelia Congesta." Botanical Magazine, vol. 56, 1829. Biodiversity Heritage Library, 2006, www.biodiversitylibrary.org/item/14216\#page/1/ mode/1up. Accessed 26 May 2017. 


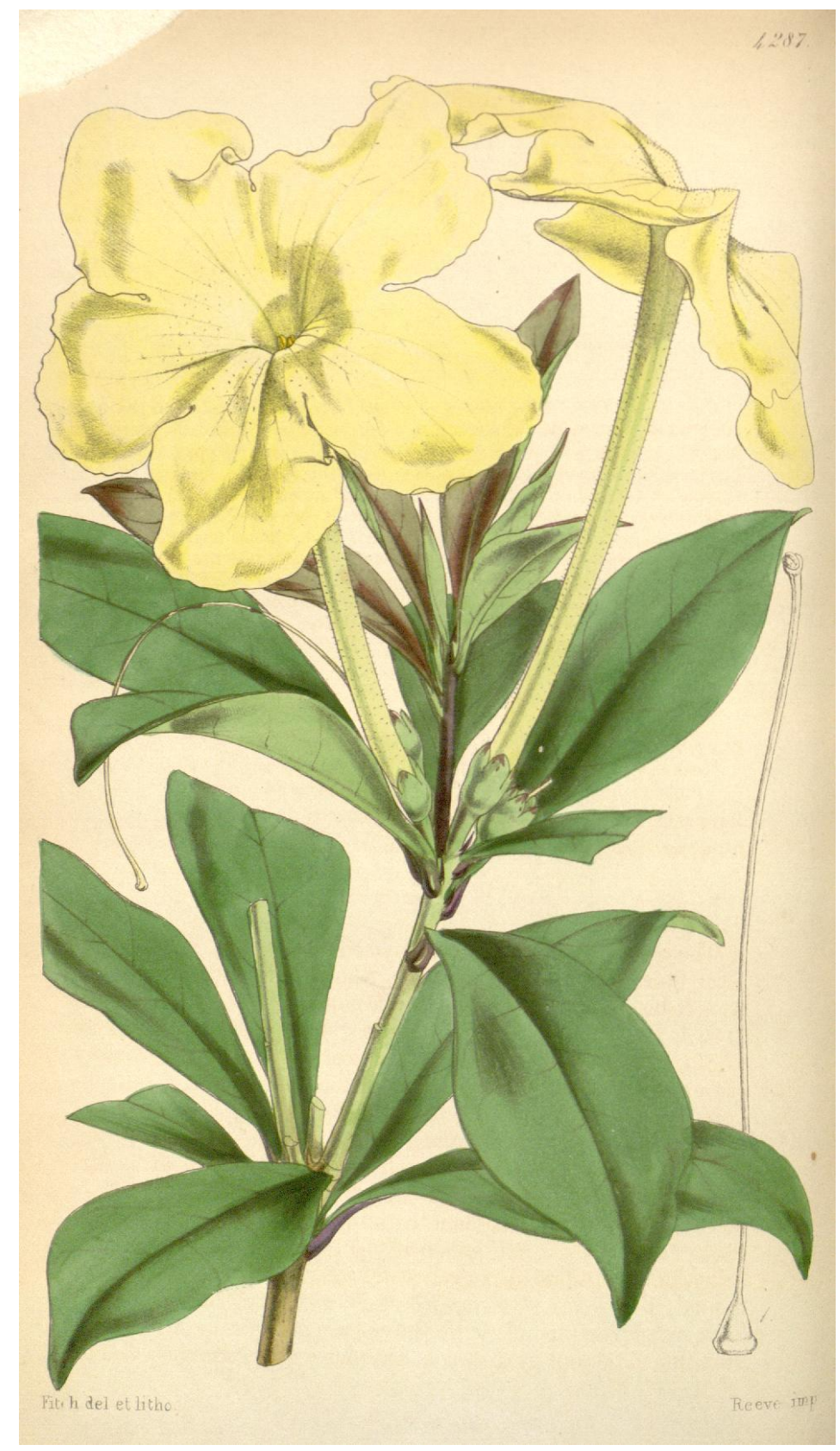

Figure 3: Walter Hood. Fitch. "Brunfelsia nitida” Botanical Magazine, vol. 73, 1847.

Biodiversity Heritage Library, 2006, biodiversitylibrary.org/page/434863. Accessed 20 May 2017. 


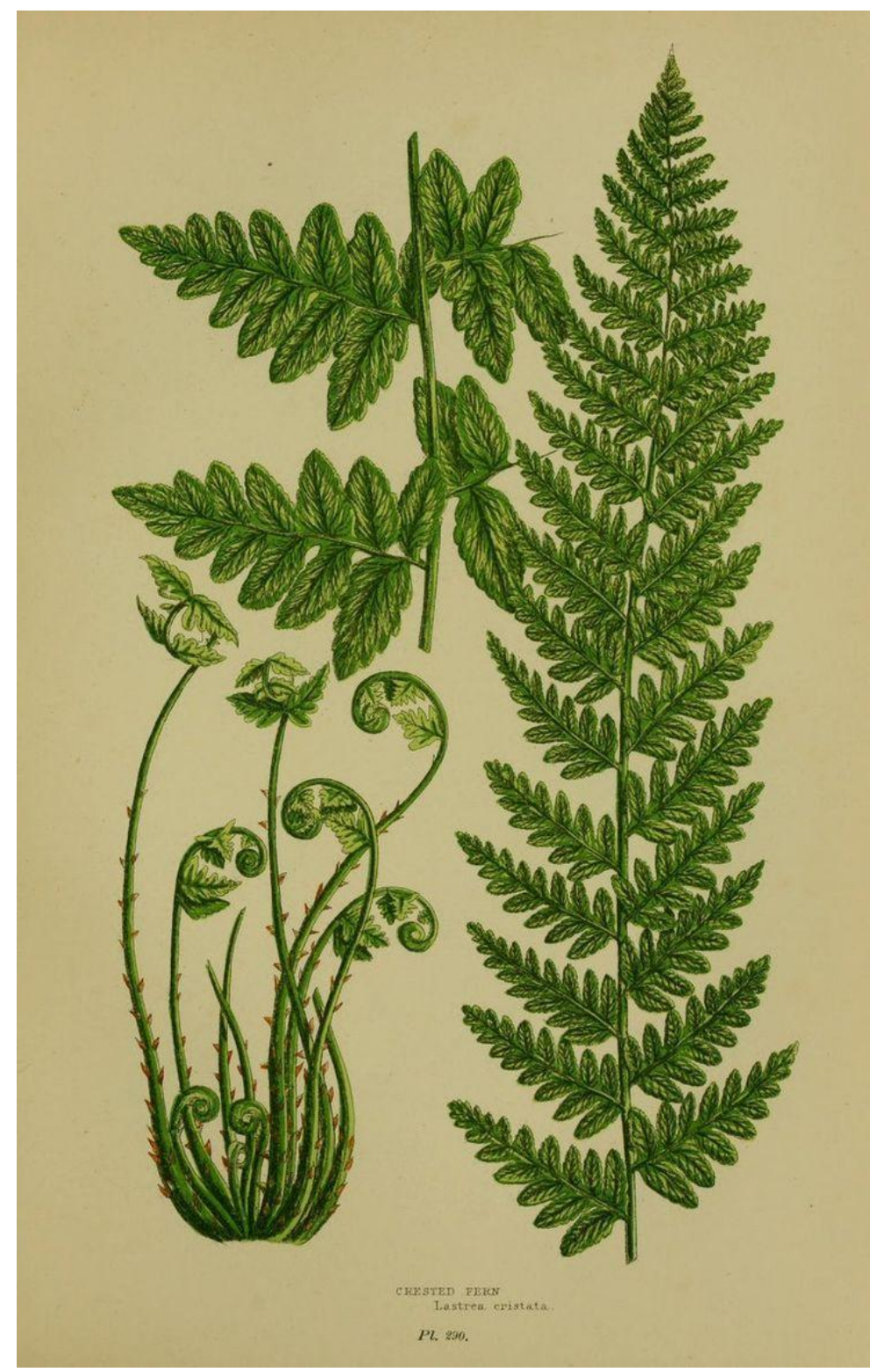

Figure 4:. Anne Pratt. "Crested Fern." The Ferns of Great Britain, and Their Allies The Club-Mosses, Pepperworts, and Horsetails, The Society of Promoting Christian Knowledge, 1850, pt. 290. 
correspondence between the distribution of the branches on the tree and the veins in the leaf. The veins are clustered or whorled with a nearly parallel venation at the point where

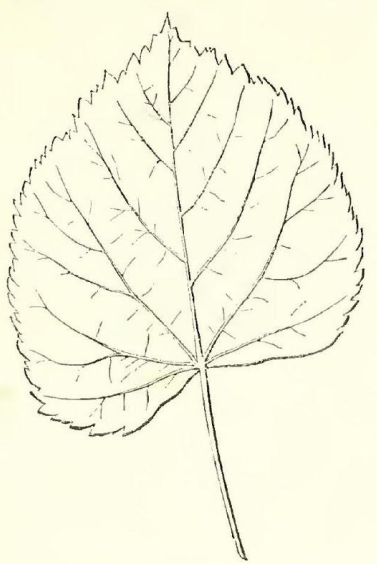

Fig, 0, LIME.

they begin to come off; the lateral veins making, with the midrib, an ansle of $42^{\circ}$, and the veins proceeding from them an angle of

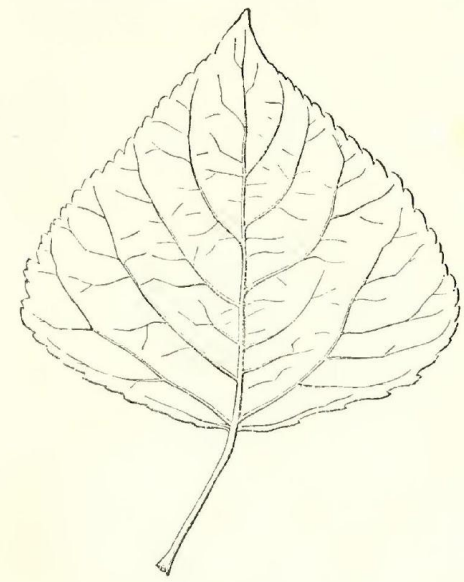

Fig. 10, Poplat.

$50^{\circ}$-these last, corresponding with the angle of the peduncle, form the branch. A curious observer will in like manner discover that the horse-chesnut, which sends off at the top of its bare trunk seven branches, has its leaf commonly divided into seven leaflets; whilst the sycamore, sending off at eight or ten feet from the ground fonr or five large branches, has a long leaf-stalk dividing into five midribs. In like manner, laburnum and broom, with their triplet leaves, divide into three main branches; and rhododendrons, barberries, and azaleas, whose leaves issue from the stem in whorls, branch in a kindred manner. Not only these, but the triplet leaf and stalk of the marsh trefoil, the wood sorrel, the clover, adopt the law in question; as do likewise the lady's-mantle, geranium, mallow, and lupin, with their clustered leaves or midribs

\section{THE NEW FISH.}

' $\mathrm{T}$ was annonneed in our last that a new 1 fish had been introdnced into our waters from Wallaclia. The Acclimatisation Society has received fourteen living specimens from Sir Steplien Lakeman's estate at Kapochein, or rather from the river Argich which flows past that nobleman's Wallachian domain. A brief notice of these visitors may prove acceptable as an adjunet to the portrait which stands above it. It shonld be memised that this species is noticed in Yarrell's Britisl Fishes; not that this author believed it a native, but because it had the reputation of having been found here, on the faith of a paragraph in Sibbald's "Seotic Illustrata." "There is no doubt, that the conclusion alrived at was a wrong one, not admitted by Cuvier and Valenciennes in their rreat work on the "Natural History of Fishes," who state that its distribution in Europe does not extend to the British Isles,

The silurus was originally classed by Cuvier between the pike and salmon families. To the former of these it may be supposed to claim kindred by its yoracioss habits, and to the latter, if all accounts be true, by the excellence of its flesh as an article of food. Notwithstanding these somewhat poetical affinities, it has another position assigned to it now. One evident characteristic in this fish is the absence of true scales, a feature which characterizes the group to which it belongs. Another important difference will be noticed in the great length of the anal fin, which extends to the tail; but, above all, the barbules will attract attention. Whether or not these are to be consiclered as sulustitutes for beard and moustaehes, piobably the

Figure 5: "Lime" and "Poplar." Science-Gossip, vol. 1, 1865, pp. 56. Biodiversity

Heritage Library, 2006, biodiversitylibrary.org/item/109228\#page/7/mode/1up. Accessed

16 May 2017. 


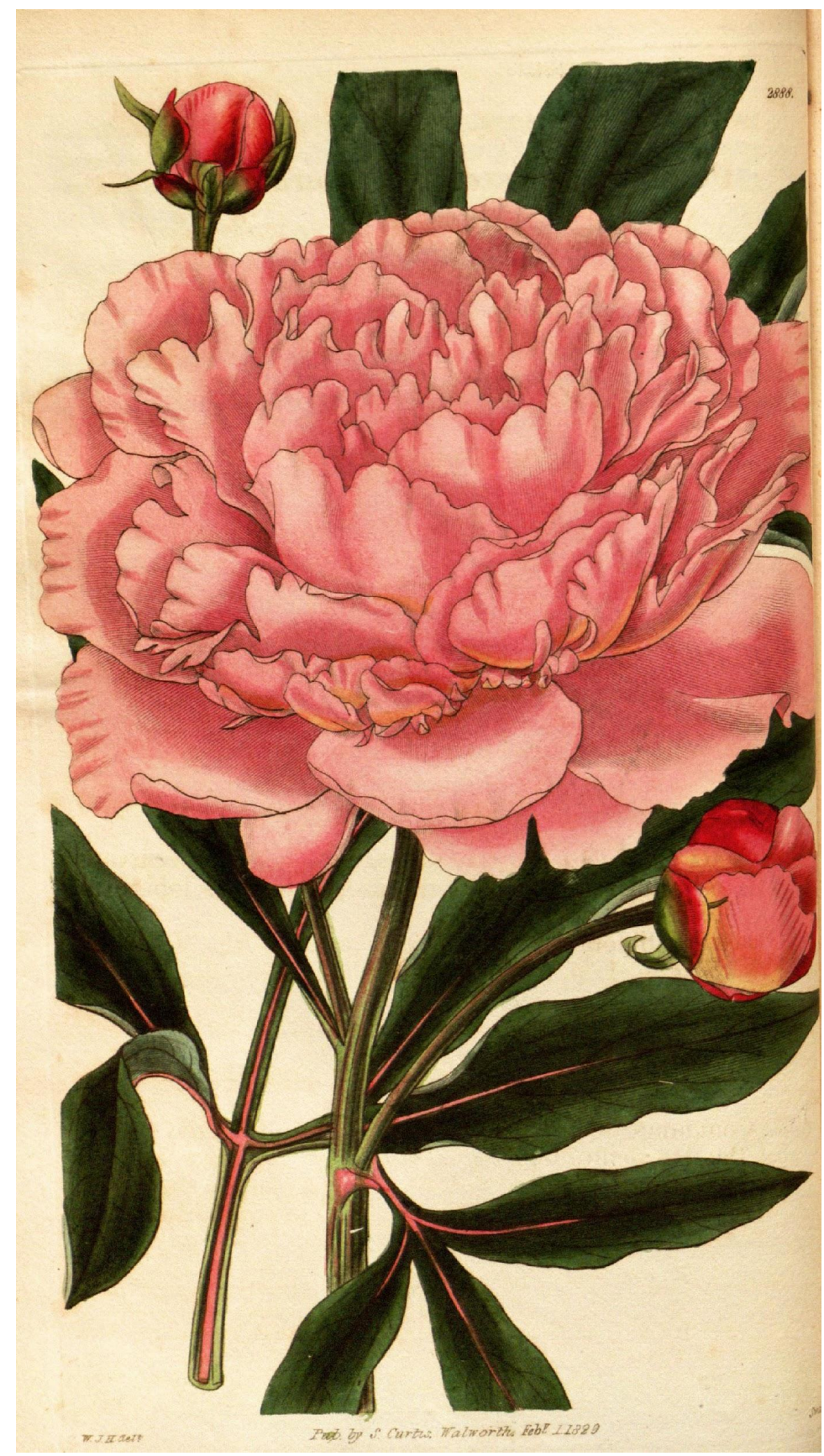

Figure 6: William J. Hooker. "Poeonia Albiflora.” Botanical Magazine, vol. 56, 1829. Biodiversity Heritage Library, 2006, www.biodiversitylibrary.org/item/14216\#page/1/ mode/1up. Accessed 26 May 2017. 


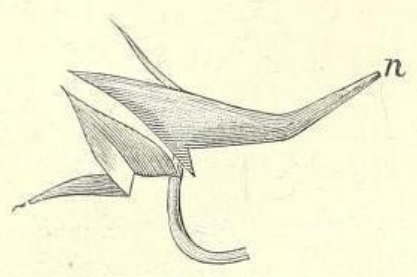

Fig. 20.-Tropøeolun.

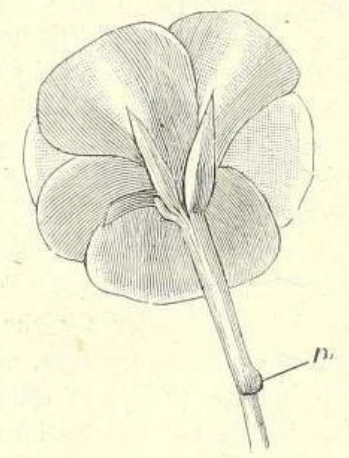

Fig. 23.-Geranium.

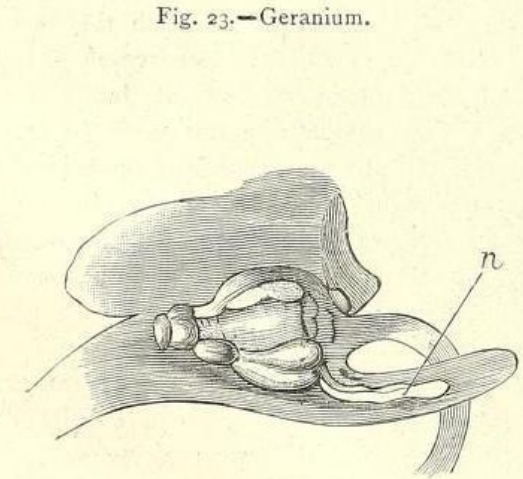

Fig. 26.-Viola tricolor.

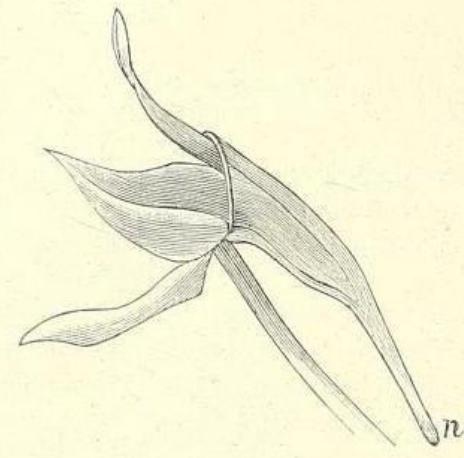

Fig. 2t,-Nasturtium.

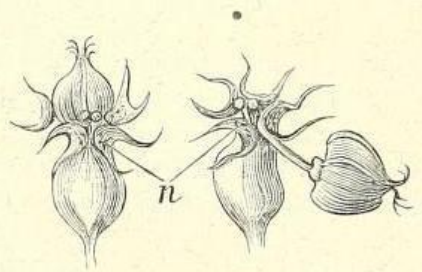

Fig. 24.-Spurge.

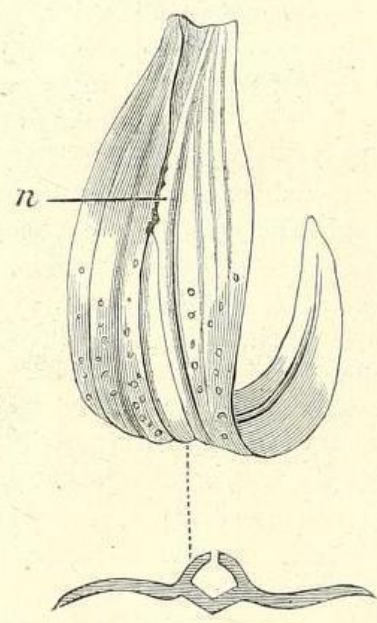

Fig. 27.-Garden Lily: $a$, entrance to

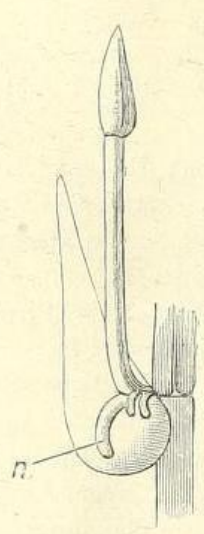

Fig. 22,-Arabis.

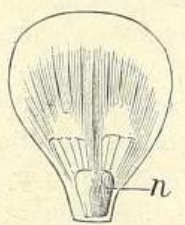

Fig. 25,-Buttercup.

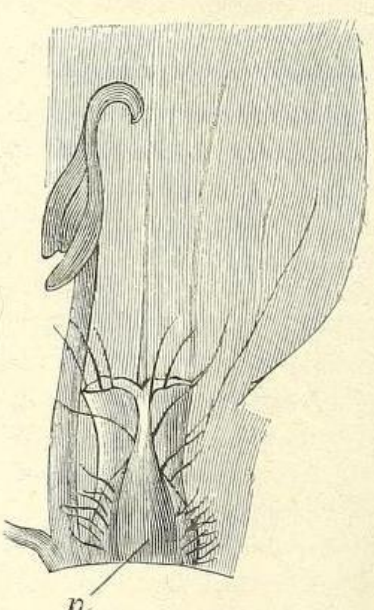

Fig. 28.-Nemophila maculata.

Figure 7: “On Nectaries.” Science-Gossip, vol. 29, 1893, pp. 36. Biodiversity Heritage

Library, 2006, biodiversitylibrary.org/page/44011908. Accessed 20 May 2017. 


\section{TOADSTOOLS.}

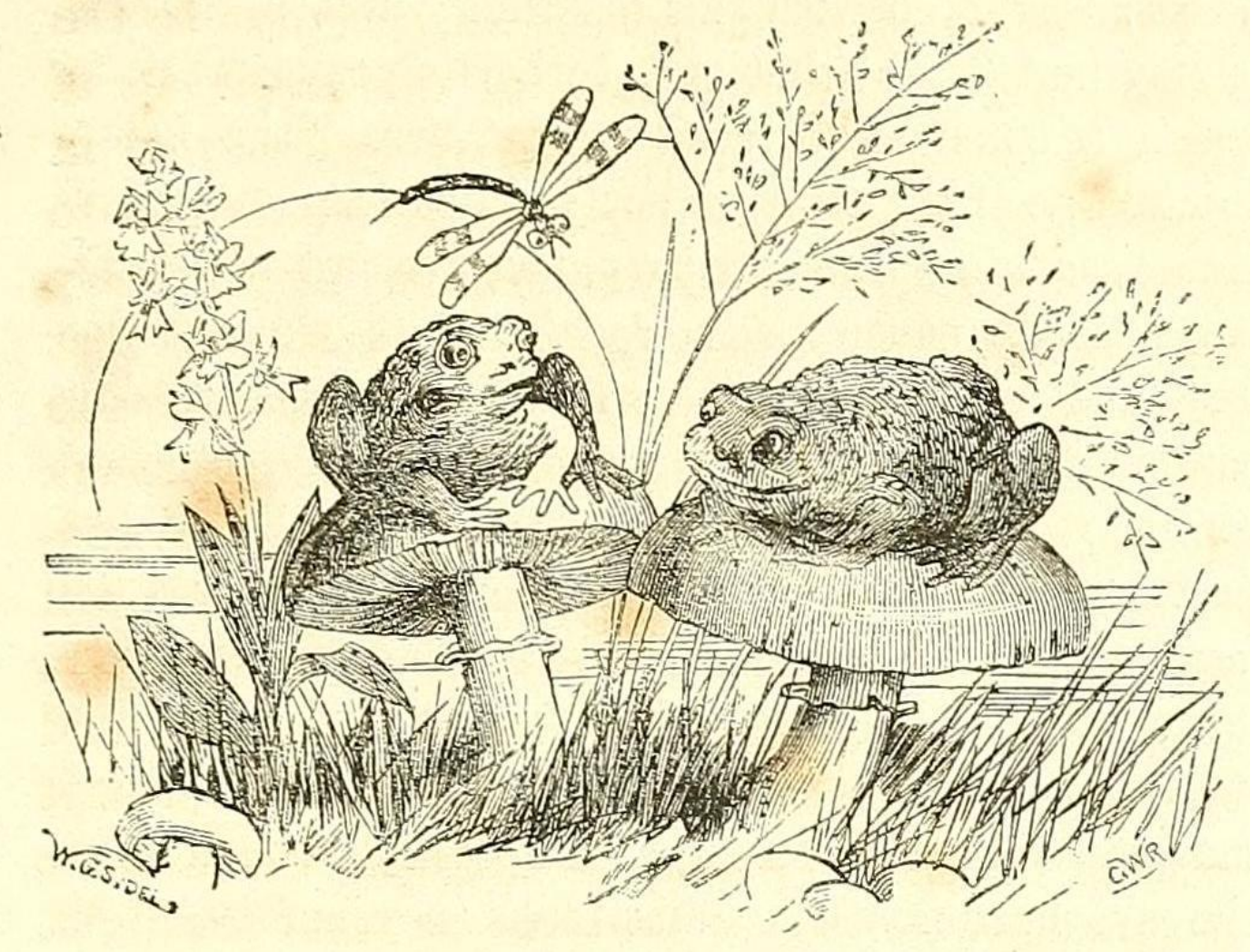

Figure 8: George Worthington Smith. “Toadstools.” Science-Gossip, vol. 1, 1865, pp. 225. Biodiversity Heritage Library, 2006, biodiversitylibrary.org/page/35145007. Accessed 26 May 2017. 
Works Cited

"A List of the Subscribers to the Flora Londinensis" Flora Londinensis, William Curtis, 1777. Biodiversity Heritage Library, 2006, biodiversitylibrary.org/item/127330\#page/7 /mode/1up. Accessed 31 May 2017.

“A Hint for Contributors.” Science-Gossip, vol. 1, 1865, pp. 120. Biodiversity Heritage Library, 2006, biodiversitylibrary.org/item/109228\# page/7/mode/1up. Accessed 16 May 2017.

B. Correspondence. “Jerusalem Artichoke.” Science-Gossip, vol. 1, 1865, pp. 143. Biodiversity Heritage Library, 2006, biodiversitylibrary.org/item/109228\#page/7/mode/1up. Accessed 16 May 2017.

B. L. "Hats Off." Science-Gossip, vol. 3, 1867, pp. 185. Biodiversity Heritage Library, 2006, biodiversitylibrary.org/page/1780881. Accessed 16 May 2017.

Bevan-Jones, Robert. Poisonous Plants: A Cultural and Social History, Windgather Press, 2009. Google Books, books.google.ca/books?id=4KOmAwAAQBAJ\&printsec=frontcover $\# \mathrm{v}=$ onepage $\& \mathrm{q} \& \mathrm{f}=$ false

Browne, E. Janet. Charles Darwin: The power of place, Volume 2. Princeton University Press, 2002.

Butterton, Harry. "The Derby Arboretum." History Today, vol. 43, 1993, pp. 62-63. Academic OneFile, go.galegroup.com/ps/i.do? $\mathrm{p}=\mathrm{AONE} \& \mathrm{sw}=\mathrm{w} \& \mathrm{u}=\mathrm{rpu} \_$main $\& \mathrm{v}=2.1 \& \mathrm{id}=\mathrm{GALE}$ \%7CA13353189\&it=r\&asid=a0bc2b71e7289d08a8c766da58f8ffff. Accessed 22 May 2017.

Charlesworth, Michael. "The Imaginative Dimension of an Early Eighteenth-Century Garden: Wentworth Castle." Art History, vol. 28, no. 5, 2005, pp. 626-647. 
Collins, Wilkie. The Moonstone, Harper \& Brothers, 1868. Google Books, books.google.ca/ books?id=FmsOAAAAQAAJ\&printsec=frontcover $\# \mathrm{v}=$ onepage $\& \mathrm{q} \& \mathrm{f}=$ false.

Cooke, Mordecai Cubitt. “What's Your Hobby?” Science-Gossip, vol. 1, 1865, pp. 2-3. Biodiversity Heritage Library, 2006, biodiversitylibrary.org/item/109228\#page /7/mode/1up. Accessed 16 May 2017.

---. "Short Commons." Science-Gossip, vol. 1, 1865, pp. 49-50. Biodiversity Heritage Library, 2006, biodiversitylibrary.org/item/109228\#page/7/mode/1up. Accessed 16 May 2017.

Creese, Walter. "Imagination in the Suburb." Nature and the Victorian Imagination. Edited by G. B. Tennyson and U. C. Knoepflmacher, University of California Press, 1977, pp. 4967.

Curtis, William. Botanical Magazine, vol. 1, 1787. Biodiversity Heritage Library, 2006, biodiversitylibrary.org/page/468631. Accessed 26 May 2017.

---. Botanical Magazine, vol. 3, 1790. Biodiversity Heritage Library, 2006, biodiversitylibrary.org/page/469099. Accessed 26 May 2017.

---. "Scabiosa Arvensis." Flora Londinensis, or, Plates and descriptions of such plants as grow wild in the environs of London, Volume 4, illustrated by James Sowerby, et al., 1789.

Darwin, Charles. Correspondence. "Hedgehogs." Science-Gossip, vol. 3, 1867, pp. 280. Biodiversity Heritage Library, 2006, biodiversitylibrary.org/page/1780881. Accessed 16 May 2017.

Drayton, Richard H. “From Royal to Public: The 'Reform’ of Kew, 1820-41.” Nature's Government: Science, Imperial Britain, and the 'Improvement' of the World, Yale University Press, 2000, pp. 129-169.

Elliott, P. A. "The Derby Arboretum (1840): The First Specially Designed Municipal Public Park 
in Britain." Midland History, vol. 26, no. 1, 2001, pp. 144-176.

English, Mary P. Mordecai Cubitt Cooke: Victorian Naturalist, Mycologist, Teacher \& Eccentric. Biopress, 1987.

Field, Henry. Memoirs of the Botanic Garden at Chelsea Belonging to the Society of Apothecaries of London. Gilbert and Rivington, 1878. Google Books, books.google.ca/books?id=oRIAAAAAQAAJ\&printsec=frontcover\&source=gbs_ge_su mmary_r\&cad $=0 \# v=$ onepage $\& q \& \mathrm{f}=$ false. Accessed 29 May 2017.

Gardham, Julie. “Curtis’s Botanical Magazine” Glasgow University Special Collections Department, The University of Glasgow, 2004.

Gaskell, Elizabeth. Mary Barton: A Tale of Manchester Life, Volume. 1. Chapman and Hall, 1850. Google Books, books.google.ca/books?id=qqROAAAAcAAJ\&printsec=frontcover $\# \mathrm{v}=$ onepage $\& \mathrm{q} \& \mathrm{f}=$ false.

Hawkins, Stephanie L. American Iconographic: National Geographic, Global Culture, and the Visual Imagination. University of Virginia Press, 2010.

Holland, Robert. “On Some Imperfectly Developed Flowers.” Science-Gossip, vol. 1, 1865, pp. 103-5. Biodiversity Heritage Library, 2006, biodiversitylibrary.org/item/109228\# page/7/mode/1up. Accessed 16 May 2017.

---. "Notes on Local Names." Science-Gossip, vol. 1, 1865, pp. 35-6. Biodiversity Heritage Library, 2006, biodiversitylibrary.org/item/109228\# page/7/mode/1up. Accessed 16 May 2017.

Hooker, William. Curtis's Botanical Magazine, vol. 54, 1827. Biodiversity Heritage Library, 2006, www.biodiversitylibrary.org/item/14338\#page/1/mode/1up. Accessed 26 May 2017. 
---. Curtis's Botanical Magazine, vol. 55, 1828. Biodiversity Heritage Library, 2006, www.biodiversitylibrary.org/item/14215\#page/1/mode/1up. Accessed 26 May 2017.

---. Curtis's Botanical Magazine, vol. 56, 1829. Biodiversity Heritage Library, 2006, www.biodiversitylibrary.org/item/14216\#page/1/mode/1up. Accessed 26 May 2017.

Lankester, Phebe. Wild Flowers Worth Notice: Being a Selection from the British Flora of some of our Native Plants, which are most Attractive from their Beauty, Uses, Or Associations. Hardwicke, 1861.

Lazarus, Maureen, Heather Pardoe and Deborah Spillards. The Paradise Garden. National Museum Wales, 1997.

Lightman, Bernard. Victorian Popularizers of Science: Designing Nature for New Audiences. University of Chicago Press, 2007.

Pratt, Anne. The Ferns of Great Britain, and Their Allies The Club-Mosses, Pepperworts, and Horsetails, The Society of Promoting Christian Knowledge, 1850. Biodiversity Heritage Library, 2006, www.biodiversitylibrary.org/item/201285\#page/5/mode/1up. Accessed 20 May 2017.

Repucci, Sheri. “The Other Side of Miasma: 'Good' Air, Public Parks, and the Rise of Landscape Design in 19th-Century England." Victorian Studies Across the Disciplines, Victorian Studies Network Symposium, 23 Oct 2015, York University, Toronto, ON. Conference Presentation.

Sims, John. "Preface." Curtis's Botanical Magazine, vol. 15, 1801. Biodiversity Heritage Library, 2006, www.biodiversitylibrary.org/item/14276\#page/2/mode/1up. Accessed 17 Apr. 2017.

Tait, Hugh. Five Thousand Years of Glass. University of Pennsylvania Press, 2004. 
Walford, Edward. "Hyde Park." Old and New London, Volume 4. London: Cassell, Petter \& Galpin, 1878, pp. 375-405.

Willes, Margaret. The Gardens of the British Working Class. Yale University Press, 2014.

\section{Figure Sources}

“Fig. 9 Lime.” Science-Gossip, vol. 1, 1865, pp. 56. Biodiversity Heritage Library, 2006, biodiversitylibrary.org/item/109228\#page/7/mode/1up. Accessed 16 May 2017.

“Fig. 10 Poplar.” Science-Gossip, vol. 1, 1865, pp. 56. Biodiversity Heritage Library, 2006, biodiversitylibrary.org/item/109228\#page/7/mode/1up. Accessed 16 May 2017.

Fitch, Walter Hood. “Brunfelsia nitida” Botanical Magazine, vol. 73, 1847. Biodiversity Heritage Library, 2006, biodiversitylibrary.org/page/434863. Accessed 20 May 2017.

Hooker, William J. “Horkelia Congesta.” Curtis’s Botanical Magazine, vol. 56, 1829. Biodiversity Heritage Library, 2006, www.biodiversitylibrary.org/item/14216\#page/1/ mode/1up. Accessed 26 May 2017.

---. "Poeonia Albiflora." Curtis's Botanical Magazine, vol. 56, 1829. Biodiversity Heritage Library, 2006, www.biodiversitylibrary.org/item/14216\#page/1/ mode/1up. Accessed 26 May 2017.

“On Nectaries.” Science-Gossip, vol. 29, 1893, pp. 36. Biodiversity Heritage Library, 2006, biodiversitylibrary.org/page/44011908. Accessed 20 May 2017.

Pratt, Anne. "Crested Fern." The Ferns of Great Britain, and Their Allies The Club-Mosses, Pepperworts, and Horsetails, The Society of Promoting Christian Knowledge, 1850, pt. 290. Biodiversity Heritage Library, 2006, www.biodiversitylibrary.org/item/201285 \#page/5/mode/1up. Accessed 20 May 2017. 
Smith, Worthington George. “Toadstools.” Science-Gossip, vol. 1, 1865, pp. 225. Biodiversity Heritage Library, 2006, biodiversitylibrary.org/page/35145007. Accessed 26 May 2017. Sowerby, James. “Centaurea Montana.” Botanical Magazine, vol. 3, 1790. Biodiversity Heritage Library, 2006, biodiversitylibrary.org/page/469099. Accessed 26 May 2017. 